DOI: https://doi.org/10.24144/2409-6857.2018.1(51).110-116

УДК 339.9

\author{
Ципліцька О.O.
}

\title{
СОЦІАЛЬНІ ВИМІРИ МОДЕРНІЗАЦЇ УКРАЇНСЬКОЇ ЕКОНОМІКИ: ВИКОРИСТАННЯ ЄВРОПЕЙСЬКОГО ДОСВІДУ
}

\begin{abstract}
У статті розкрито особливості та наслідки проведення соиіальної політики в краӥнах ЄС, щзо переважно брали за основу модель сочіальної політики О. ф. Бісмарка. Визначено, щуо в ході проведення ряду реформ, які відповідали різним ичілям національних економік, у моделях соціальної політики краӥн Свропи утворилися суттєві розбіжності, обумовлені соціально-економічними, інституціональними та територіально-адміністративними чинниками. За таких умов отримати для Украӥни взірець моделі системи сочіального забезпечення неможливо. Проте окремі заходи, стратегії та інструменти можуть бути успішно використані для їх реалізації в Україні.
\end{abstract}

Ключові слова: сочіальна політика, модернізація наџіональної економіки, модель сочіальної політики, Свропейський Союз, сочіальна держава.

Постановка проблеми. Успіх реформування економіки передбачає, що цей процес відбувається у тандемі із соціальною та політичною сферами, які мають відповідати новітнім умовам господарювання. Тож поряд із модернізацією економічних та політичних відносин потребує модернізації соціальна політика держави, базисом якої виступає економіка, яка виведена із «тіні», має низький рівень корупції, стійкі державні та суспільні інститути.

Соціальна політика України вже рухається у напрямку європейських стандартів, однак реформи враховують й специфіку розвитку національної економіки, яка потребує подальшої лібералізації та модернізації.

Тривалий шлях у формуванні сучасної соціальної політики пройшли країни Європейського Союзу. Вихідною моделлю для багатьох країни стала модель соціальної політики Отто фон Бісмарка, яка грунтувалася на засадах обов'язковості соціального страхування, принципах паритетності розподілу страхового навантаження між працівниками та роботодавцями. Втім, розходження векторів у соціально-економічному розвитку європейських країн внесли в неї почасти кардинальні зміни, що було зумовлене інституціональними, політичними, історико-культурними та економічними причинами. Досвід країн $\mathrm{EC}$, особливо тих, хто ввійшов до Союзу нещодавно, може стати орієнтиром у майбутніх стратегічних пріоритетах соціальної політики України.

(C) Ципліцька Олена Олександрівна, к.е.н., доцент, кафедра економічної теорії та міжнародної економіки, Чорноморський національний університет імені Петра Могили, м. Миколаїв, тел.: 0503948424, email: o.liakhovetz@gmail.com
Аналіз останніх досліджень та публікацій. Принципи формування соціальної політики відповідно до умов ринкової економіки, зокрема, у трансформаційних економіках почали досліджуватися ще у 1990-х - початку 2000-х роках в працях С.О. Войтовича, який проаналізував зв'язок соціальних інститутів із формою власності та характером влади; Є. Головахи та Н. Паніної, які зосередили увагу на становленні нових соціальних інститутів в українському суспільстві; О. Бєлєнка, що розглянув еволюцію системоутворюючих інститутів українського суспільства; Н.А. Балтачеєвої, праці якої присвячені проблемам формування соціальної політики в Україні та багатьох інших. На сучасному етапі дослідженнями напрямів реформування соціальної політики в Україні та іiї адаптації до європейських стандартів займаються такі учені як М. Кремер, Б. Пальє, В.А. Скуратівський, В.П. Трощинський, I.А. Чекан тощо. В їх роботах проаналізовано існуючі проблеми соціальної політики, їх інституціональне, соціальноекономічне та політичне підгрунтя, а також визначена необхідність зміни чинного законодавства під стандарти Європейського Союзу.

Виділення раніше невирішених частин загальної проблеми. Разом з тим, досліджень, в яких детально були $б$ розглянуті моделі соціальної політики країн $Є С$ та які з них можуть стати повністю або частково еталоном для реформування вітчизняної системи соціального захисту населення, небагато. Крім того, слід зважати, що беручи за основу модель соціальної економіки Отто фон Бісмарка, кожна країна $Є \mathrm{C}$ визначила свій шлях соціально-економічного розвитку, який найкращим чином адаптований до їх інституціонального середовища та потреб 
національної економіки. Тож дане дослідження присвячене аналізу ступеня диференціації європейських моделей системи соціального захисту в залежності від історико-політичних та соціально-економічних факторів їх розвитку та визначенню тих елементів цих моделей, які можуть бути успішно використані в Україні.

Формулювання цілей статті. Метою статті $\epsilon$ узагальнення досвіду та моделей соціальної політики країн Європейського Союзу та використання їх для визначення подальших напрямів соціальних реформ, орієнтованих на підтримку модернізації національної економіки.

Опис основного матеріалу дослідження. Соціальна політика в кожній державі представляє собою один 3 ключових інститутів національної економіки, спрямований на підтримку та забезпечення відповідних соціальних умов існування людини в даному суспільстві. Потреба у соціальній політиці як суспільному інституті викликана необхідністю «упорядкування тієї сфери суспільного життя людей, яка стосується їх становища у соціальній структурі, відносин між ними як представниками різних класів, націй, професійно-кваліфікаційних та інших соціальних груп» $[5$, с. 7$]$.

Модель соціальної політики в Україні через трансформаційну кризу все ще не набула остаточної ідеологічної форми, оскільки за весь період незалежності держави була спрямована переважно на забезпечення необхідної суми надходжень до бюджету, фондів соціального страхування та пенсійного фонду, що відчували постійний дефіцит коштів. В той же час за використання зваженого підходу до формування соціальних гарантій соціальна політика має значний потенціал у вирішенні основних суспільних завдань країни. Він має засновуватися на виборі основних функціональних цілей такої політики. Критерії такого вибору є здебільшого соціальноекономічними та інституціональними i грунтуються на потребах економіки, орієнтовнаних на досягнення європейських стандартів, на зближення векторів соціально-економічного розвитку національної та успішних зарубіжних економік.

За офіційними даними Держкомстату [1], сума заробітної плати в Україні за 2016 рік склала 877276 млн грн, що майже на 100 млн грн більше, ніж у 2015 році. В той же час за І півріччя 2017 року вона становила 536242 млн грн, що потенційно забезпечує перевищення заробітної плати у 2017 р. рівня 2016 р. в номінальному вираженні. При цьому сума надходження єдиного внеску за 2016 рік склала 131826,8 млн грн, що на 53863,1 млн грн менше, ніж у 2015 році. За I півріччя 2017 року сума надходжень становить 84318,1 млн грн. При цьому наявний дохід за I півріччя 2017 року збільшився на $18,8 \%$ порівняно 3 I півріччям 2016 року і склав 769395 млн грн.

Аналіз показників трудових доходів та відрахувань свідчить про зростання перших у номінальному та реальному вираженні. Разом 3 тим, єдиний внесок до фондів соціального страхування має тенденцію до скорочення. Переважно це обумовлено зниженням ставки у 2016 році до $22 \%$.

Стандарти Європейської соціальної хартії вимагають, щоб рівень мінімальної зарплати становив не менше, ніж 2,5 прожиткових мінімуми, а співвідношення мінімальної та середньої зарплат повинно складати не нижче, ніж 1:3 [6]. Якщо брати до уваги збільшення мінімальної заробітної плати у 2017 році з рівня 1600 до 3200 гривень та у 2018 році збільшення до 3723 грн, а встановлення прожиткового мінімуму на рівні 1700 грн, то можна побачити, що вимог все ще не досягнуто - мінімальна заробітна плата складатиме всього 2,19 прожиткових мінімумів. При цьому все ще залишається значною частка населення, що живе на доходи нижче фактичного прожиткового мінімуму: якщо у 2014 році вона складала $16,7 \%$, то у 2015 році $51,9 \%$, а у 2016 році $-51,1 \%$, хоча цифри для законодавчо встановленого прожиткового мінімуму є значно нижчими - у 2015 році - 6,4\%, у 2016 році - 3,8\%. Квінтильний коефіцієнт диференціації загальних доходів за останні 3 роки не змінювався i становив 1,9 разів, а коефіцієнт фондів (по загальних доходах) - скоротився у 2016 році з 3,2 рази до 3 разів [1].

Середня зарплата по країні становить 7104 грн.станом на 31 грудня 2017 року, що складає у співвідношенні 3 мінімальною заробітною платою 1:2,22. Власне, 31 квітня 2015 по 1 грудня 2016 року воно навіть перевищувало 1:3. Однак різке підняття в 2 рази мінімальної заробітної плати з 1 січня 2017 року знову призвело до скорочення пропорції. Втім, можна простежити поступову позитивну динаміку руху в напрямку європейських стандартів соціальної політики.

В табл. 1 продемонстровано темпи приросту номінальних значень прожиткового мінімуму, мінімальної заробітної плати та середньомісячної заробітної плати по країні.

Порівняльний аналіз показників у табл. 1 свідчить, що темпи приросту прожиткового мінімуму не відповідають зростанню рівня цін, так само як і мінімальної заробітної плати. 
Таблиця 1

Темпи приросту середньорічних показників доходу в Україні, 2015-2018 рр.*

\begin{tabular}{|c|c|c|c|c|}
\hline \multirow{2}{*}{ Дата } & \multicolumn{3}{|c|}{ Темпи приросту порівняно з попереднім періодом, \% } \\
\cline { 2 - 5 } & $\begin{array}{c}\text { Прожитковий } \\
\text { мінімум }\end{array}$ & $\begin{array}{c}\text { Мінімальна } \\
\text { заробітна плата }\end{array}$ & $\begin{array}{c}\text { Середня заробітна } \\
\text { плата }\end{array}$ & Приріст цін \\
\hline 01.09 .2015 & 13 & 13 & 16 & 41.4 \\
\hline 01.05 .2016 & 5 & 5 & 18 & 6.6 \\
\hline 01.12 .2016 & 10 & 10 & 9 & 6.9 \\
\hline 01.01 .2017 & 0 & 100 & 16 & 1.1 \\
\hline 01.05 .2017 & 5 & 0 & 25 & 5.1 \\
\hline 01.10 .2017 & 0 & 0 & 6 & - \\
\hline 01.12 .2017 & 5 & 0 & - & - \\
\hline 01.01 .2018 & 0 & 16 & - & - \\
\hline
\end{tabular}

*Розраховано автором на основі $[1 ; 2 ; 3 ; 4]$

Втім, іiі підвищення в 2 рази 31 січня 2017 року дещо виправило ситуацію, однак реальний ii розмір залишається досить низьким. Середньомісячна заробітна плата по економіці в номінальному обсязі зростає досить швидкими темпами, співставними із динамікою рівня цін.

Середній індекс реальної заробітної плати в Україні за період 2010-2016 рр. склав лише $102,7 \%$, тобто щорічно реальний $\dddot{11}$ розмір збільшувався в середньому на $2,7 \%$, що $\epsilon$ непоганим 3 погляду середніх темпів щорічного падіння реального ВВП в розмірі $1,53 \%$ за період 2010-2016 рр. Цей показник також відповідає темпам зростання заробітної плати в Єврозоні, де починаючи 32011 року вони склали в середньому $2 \%$, у 2016 році скоротилися до рівня 1,4\% на кінець року, а в липні 2017 знову досягли $2 \%$ [8].

Моделі соціальної політики країн Європейського Союзу можуть стати основою для перегляду існуючих соціальних гарантій в Україні, i внаслідок їх удосконалення покращити соціальний захист населення.

Основою соціальної політики для більшості західноєвропейських країн стала модель О. фон Бісмарка, яка трансформувалася та набувала своїх специфічних рис всередині кожної країни. Визначення напряму реформ у соціальній політиці країн здійснювалося переважно тим, яка політична сила прийшла до влади. Періодичні зміни урядів соціалдемократів та лібералів обертали реформи від одних цілей до інших. Тому неможливо стверджувати, що системи соціального страхування вже остаточно склалися в цих країнах, вони продовжують трансформуватися в пошуках певної ідеальної для даного суспільства моделі.

Першочерговими причинами, які викликали необхідність проведення соціальних реформ в країнах Західної та Східної Європи, виступали економічні - безробіття та інфляція (Німеччина, Франція, Голландія, Бельгія, Італія), посилення майнової диференціації та незадовільний рівень соціального забезпечення (Швеція, Швейцарія), в деяких країнах (Іспанія) - децентралізація та факт вступу до $€ C$, в східноєвропейських державах - трансформаційна криза 1980-90-х років (Чеська Республіка, Словаччина, Угорщина, Польща). У табл. 2 представлено зміст реформ відповідно до проблем, що вирішувалися, та особливості й наслідки їх проведення.

Зміст соціальних реформ у свропейських країнах

Таблиця 2

\begin{tabular}{|c|c|c|}
\hline Країна & Зміст реформ & $\begin{array}{l}\text { Особливості та наслідки проведення } \\
\text { реформ }\end{array}$ \\
\hline \multicolumn{3}{|c|}{ Збільшення рівня безробіття } \\
\hline Німеччина & $\begin{array}{l}\text { Уряд Г.Шредера: } \\
\text { - збільшення соціальних відрахувань з фонду } \\
\text { оплати праці; } \\
\text { - підвищення соціальних виплат сім'ям з дітьми } \\
\text { Уряд А.Меркель: } \\
\text { - згортання соціальних програм на користь } \\
\text { зниження оподаткування та розвитку бізнесу }\end{array}$ & $\begin{array}{l}\text { Г.Шредер створив гібрид англосаксонської } \\
\text { та скандинавської економіки. } \\
\text { А. Меркель слідувала концепції } \\
\text { соціального ринкового господарства } \\
\text { Л. Ерхарда. } \\
\text { Відбулося зростання диференціації доходів } \\
\text { після обох реформ }\end{array}$ \\
\hline
\end{tabular}


Продовження табл.2

\begin{tabular}{|c|c|c|}
\hline Франція & $\begin{array}{l}\text { - державне фінансування пенсій та допомог по } \\
\text { безробіттю («професійна солідарність»); } \\
\text { - розвиток приватних інститутів соціального } \\
\text { страхування; } \\
\text { - допомога сім’ям, боротьба із соціальною } \\
\text { ізоляцією, } \text { медичне } \\
\text { («національна солідарність») }\end{array}$ & $\begin{array}{l}\text { Реалізована модель Бісмарка призвела до } \\
\text { дуалізації суспільства на дві категорії - } \\
\text { тих, хто може розраховувати на щедре } \\
\text { соціальне страхування, та тих, для кого } \\
\text { передбачені мінімальні соціальні переваги }\end{array}$ \\
\hline Голландія & - підтримка створення робочих місць & $\begin{array}{l}\text { Завдяки децентралізації та можливості } \\
\text { місцевих органів влади втручатися у у } \\
\text { реформи, вони були успішно реалізовані. } \\
\text { Відбулася інтеграція профспілок }\end{array}$ \\
\hline Італія & $\begin{array}{l}\text { - захист найманих працівників через систему } \\
\text { соціального страхування }\end{array}$ & 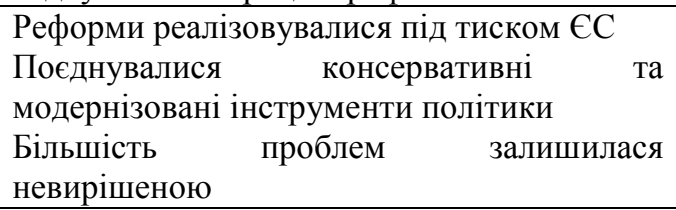 \\
\hline \multicolumn{3}{|c|}{ Високі темпи інфляції } \\
\hline Бельгія & - стримування зростання заробітних плат & 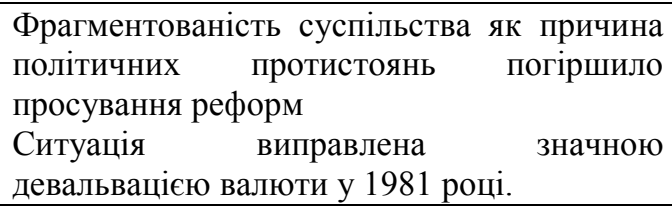 \\
\hline \multicolumn{3}{|c|}{ Нерівність у суспільстві, незадовільний рівень соціального забезпечення } \\
\hline Швеція & $\begin{array}{l}\text { - укладено соціальний пакт - узгодження між } \\
\text { робітниками та великими корпораціями умов } \\
\text { існування бізнесу }\end{array}$ & $\begin{array}{l}\text { Збільшився податковий тиск на великі } \\
\text { корпорації } \\
\text { Уряд та бізнес спрямовані на підтримку } \\
\text { повної зайнятості в економіці }\end{array}$ \\
\hline Швейцарія & $\begin{array}{l}\text { - підтримка незахищених верств населення } \\
\text { (безробітних, людей з особливими потребами та } \\
\text { матерів); } \\
\text { - надання мінімальної підтримки особам } 3 \\
\text { низькими доходами }\end{array}$ & $\begin{array}{l}\text { В ході реалізації реформ поглибилися } \\
\text { конфлікти між політичними партіями та на } \\
\text { грунті гендерної рівності } \\
\text { Завдяки реформам відбувся перехід } \\
\text { політичних цілей від компенсаційних до } \\
\text { активізаційних } \\
\text { Бенефіціарами реформ стали аутсайдери } \\
\text { ринку та жінки }\end{array}$ \\
\hline \multicolumn{3}{|c|}{ Децентралізація та приєднання до ЄС, незрілість системи соціального захисту } \\
\hline Іспанія & $\begin{array}{l}\text { - політика забезпечення доходів } \\
\text { (корпоративізм); } \\
\text { - державне забезпечення освіти і охорони } \\
\text { здоров’я (соціал-демократія); } \\
\text { - створення соціальних служб та запровадження } \\
\text { соціальної допомоги (лібералізм) }\end{array}$ & $\begin{array}{l}\text { Використовувалися інноваційні інстру- } \\
\text { ментти } \\
\text { В русі реформ був швидкий прогрес }\end{array}$ \\
\hline \multicolumn{3}{|c|}{ Трансформаційна криза } \\
\hline $\begin{array}{l}\text { Чеська } \\
\text { Республіка, } \\
\text { Угорщина } \\
\text { Словаччина } \\
\text { Польща }\end{array}$ & $\begin{array}{l}\text { - децентралізація управління соціальною } \\
\text { системою; } \\
\text { - створення триступеневої системи пенсійного } \\
\text { забезпечення (із залученням приватної форми); } \\
\text { - забезпечення прозорості управління в } \\
\text { медичній сфері; } \\
\text { - захист малозабезпечених верств населення; } \\
\text { - покращення інституційних умов для } \\
\text { самореалізації на ринку }\end{array}$ & $\begin{array}{l}\text { Пріоритетом соціальних реформ виступила } \\
\text { боротьба з бідністю } \\
\text { Неможливість швидкої реалізації реформ } \\
\text { через їх здійснення за рахунок найбідніших } \\
\text { верств населення } \\
\text { Сполучення принципів диференціації та } \\
\text { зрівнювання }\end{array}$ \\
\hline
\end{tabular}

*Складено автором за джерелом [7]

Таким чином, зміни у принципах та підходах до формування соціальної політики країн СС викликані їх економічним становищем, а також такими інституціональними чинниками як характер політичних сил при владі, ступінь втручання держави в економіку, вимоги уряду
ЕC до основних соціально-економічних показників країн-членів, етнічні та територіальні проблеми.

Успішність проведених реформ можна відслідкувати на основі ключових показників статистики зазначених країн (табл. 3 ). 
Показники ефективності соціальної політики в країнах ЄС [9]

Таблиця 3

\begin{tabular}{|l|c|c|c|c|c|c|c|c|c|}
\hline \multirow{2}{*}{ Країна } & \multicolumn{3}{|c|}{ Виплати по соціальному захисту, млн } & \multicolumn{2}{c|}{$\begin{array}{c}\text { \% соціальних внесків у } \\
\text { загальних доходах }\end{array}$} & \multicolumn{2}{c|}{ Рівень безробітт, \% } \\
\cline { 2 - 13 } & 1991 & 2000 & 2015 & 1991 & 2000 & 2015 & 1991 & 2000 & 2015 \\
\hline Німеччина & 363079.43 & 586060.87 & 847698.39 & 54.3 & 56.9 & 54.6 & 5.5 & 7.9 & 4.6 \\
\hline Франція & 266659.99 & 402573.9 & 701210.89 & 42.8 & 40.4 & 41.8 & 8.1 & 8.6 & 10.4 \\
\hline Швеція & - & 78363.15 & 128400.28 & 31.3 & 13.1 & 9.4 & 3.1 & 5.6 & 7.4 \\
\hline Австрія & 35524.31 & 58024 & 99940 & 36.4 & 33.4 & 32.3 & 3.4 & 3.9 & 5.7 \\
\hline Бельгія & 42224.86 & 61447.69 & 119303.51 & - & 33.4 & 36.4 & 6.4 & 6.9 & 8.5 \\
\hline Голандія & 72652.24 & 102543 & 194122 & 36.1 & 38.1 & 36.7 & 5.7 & 3.7 & 6.9 \\
\hline Італія & 225398.54 & 284009 & 476111 & - & 32.1 & 33.5 & 8.5 & 10 & 11.9 \\
\hline Іспанія & 90491.68 & 123077.1 & 261288.67 & - & 5.8 & 5.5 & 15.5 & 11.9 & 22.1 \\
\hline Швейцарія & 34816.2 & 62030.37 & 151633.04 & 38.2 & 35.7 & 37.5 & 1.8 & 2.7 & 4.5 \\
\hline Польща & - & 35530.27 & 76821 & - & - & 41.1 & 11.9 & 16.1 & 7.5 \\
\hline Чехія & - & 11618.32 & 31022.42 & - & 46.5 & 40.6 & 2.3 & 8.8 & 5.1 \\
\hline Угорщина & - & 9839.91 & 21835.76 & 30.4 & 34 & 30.1 & 10.1 & 6.3 & 6.8 \\
\hline Словаччина & - & 4139.69 & 13993.82 & - & 37.2 & 34.5 & 12.3 & 18.9 & 11.5 \\
\hline
\end{tabular}

“_," - немає даних

3 табл. 3 видно, що в усіх країнах виплати по соціальному захисту неухильно зростають протягом 1991-2015 років. Це пояснюється також i зростанням доходів населення та відрахувань на соціальні заходи у номінальному вираженні. Зокрема, якщо взяти до уваги \% соціальних внесків у загальних доходах, то він залишається відносно сталим протягом усього періоду дослідження. Суттєве скорочення лише відбулася у Швеції, де цей показник скоротився на $21,9 \%$, у Чехії, Угорщині та Словаччині, де зменшення питомої ваги внесків у доходах склало відповідно 5,9\%, 3,9\% та 2,7\%. У Бельгії відбулося збільшення показника порівняно 3 2000 роком на 3\%. У решти країн незначні відхилення до 2\%. Динаміка рівня безробіття свідчить, що Німеччина, Словаччина, Угорщина та Польща домоглися суттєвого його скорочення. В решті країн відбулося зростання показника порівняно з 1991 роком. Так, у Швейцарії, Швеції та Іспанії, де реформи відбувалися успішно, він збільшився в 2,4-2,5 разів та 1,4 рази відповідно. Більшою мірою це пов'язується iз фінансовою кризою, яка негативним чином відбилася на цих країнах.

Якщо звернутися до України, то за своїми стартовими умовами для соціальних реформ вона, звісно, близька до трансформаційних економік. Реструктуризація інститутів добробуту (соціального забезпечення) в цих країнах супроводжувалася появою нових суспільних проблем. Трансформаційна криза підвищила рівень безробіття, необхідно було вирішувати проблеми фінансування пенсійних виплат, медичного страхування тощо. Реформи розпочалися негайно i вимагали значної структурної перебудови.

3 1960-х по 1980-ті роки соціальні трансферти в цих країнах розподілялися або через центральний бюджет або через утворені соціальні (пенсійні) фонди. Зокрема в Чехословаччині виплати по соціальному страхуванню становили частку державного бюджету, а в Польщі та Угорщині були відокремленими у фонди соціального забезпечення. Незважаючи на численні спроби збільшити перерозподільчі можливості централізованої планової економіки, в кінці 1980-х років система соціального забезпечення в цих країнах дійшла своїх меж за рахунок зовнішнього фінансування, та незадоволеність серед громадян призвела до колапсу системи 9 листопада 1989 року, в день падіння Берлінської Стіни.

В країнах почали проводитись активні реформи, які слідували трьом основним напрямам: 1) компенсація переходу від планової до ринкової економіки; 2) економія коштів за рахунок приватизації; 3) відновлення рівноваги. Ці фази тісно пов'язувалися із специфікою реформ політики соціального захисту. В першу чергу, реформи були проведені в системі пенсійного забезпечення. В країнах були впроваджені триступеневі системи, у тому числі 
із залученням приватних пенсійних фондів. Крім того, це включало поступове збільшення ставок відрахувань та пенсійного віку. В сфері медичного забезпечення основними заходами реформ стали перезапуск системи страхування здоров'я, більш прозоре управління та фінансування системи (від оподаткування до відрахувань та від державного бюджету до самостійних фондів) поряд із появою практики приватного медичного страхування. Заходи, спрямовані на соціальний захист малозабезпечених сімей, стали пріоритетом політики, яка передбачала боротьбу з бідністю.

Як видно, ті заходи, до яких Україна вдається лише останніми роками, а саме - реформа пенсійного забезпечення (причому реалізовувала під тиском і наглядом МВФ), впровадження системи медичного страхування, ще остаточно не реалізовані, а відтак - результати цих реформ можна буде оцінити у далекому майбутньому.

Можна зазначити, що просування реформ також здійснюється «по-італійські» - в ході реформ сполучаються модернізаційні та консервативні інструменти, які не дають необхідного ефекту (жодну з соціальних реформ не можна вважати достатньо успішною або цілком завершеною). Це зумовлено тим, що якщо простежити за докомуністичними та комуністичними передумовами, то очевидним буде те, що саме вони визначали шлях сучасних реформ у цих постсоціалістичних країнах.

40-річний комунізм створив систему формальних і неформальних норм, які створили інституціональні обмеження для впровадження нежиттєздатних політичних рішень. Тож одним 3 найбільш обгрунтованих шляхів виступала підтримка та підсилення бісмаркіанських принципів соціальної політики.

Напрям реформ в країнах Центральної та Східної Свропи став неоднозначним сполученням принципів диференціації та зрівнювання. Зокрема, в Чеській Республіці пенсії фінансуються за рахунок внесків на соціальне страхування та розраховуються на основі двох сум: 1) базової фіксованої ставки, заснованої на громадянстві; 2) додаткового компонента, пов'язаного 3 доходами, що враховує професійний статус. Єдина фіксована ставка служить інструментом вирівнювання за рахунок середнього та вищого класів суспільства. В Угорщині більшість медичних послуг включені в пакет обов'язкового медичного страхування, який входить у схему обов'язкового страхування. Внаслідок цього для додаткових приватних медичних послуг залишається мало простору і через це більшість громадян мають однаковий доступ до такого забезпечення. На думку Я. Корнаї, угорська система медичного забезпечення все ще носить ознаки «ринкового соціалізму». В Польщі виплати по безробіттю фінансуються за рахунок відрахувань на соціальне страхування, але їх сума надається відповідно до фіксованої ставки. Диференційована система соціального забезпечення також існує для фермерів, які застраховані Фондом соціального страхування для фермерів (KRUS) на відміну від інших професій, які страхуються Інститутом соціального страхування (ZUS).

Дизайн соціальних реформ у країнах, що нещодавно стали членами $€ \mathrm{C}$, був продиктований загальною соціальною політикою Союзу, яка далека від неоліберальних рецептів, пропонованих Вашингтонським консенсусом.

Висновки та перспективи подальших досліджень. Більшість вказаних європейських країн застосовували стратегію Бісмарка в соціальній політиці, однак національні особливості, інституціональні системи, політичні та соціально-економічні процеси скоригували системи соціального захисту таким чином, що розходження в них стали більш помітними, ніж спільність початкової ідеології.

Щодо України, то запроваджувані реформи в сфері соціального захисту перетинаються як 3 реформами, які були реалізовані в трансформаційних економіках, проте це було зроблено, на відміну від України, раніше, швидше й успішніше, так i 3 реформами західноєвропейських держав.

Серед успішних стратегій, які можна було б перейняти у країн $\epsilon C$, можна назвати децентралізацію та залучення у хід проведення реформ місцеві органи влади та самоврядування, а також державно-приватне партнерство у сфері запровадження соціальних програм. В той же час можна визначити заходи, які не забезпечують належного результату або навіть загострюють існуючі проблеми. До таких відносяться нерівномірність розподілу соціальних пільг та гарантій серед різних категорій населення, заходи, спрямовані на скорочення соціального забезпечення незахищених верств населення без створення дієвої альтернативи.

Подальших досліджень вимагатимуть питання розробки концептуального підходу до використання досвіду найбільш успішних європейських країн шляхом співставлення їх інституціональних умов 3 вітчизняними. Це допоможе визначити орієнтири соціальних реформ, які слід провести в майбутньому задля підвищення рівня економічного добробуту населення та покращення соціальних стандартів. 


\section{ПЕРЕЛІК ВИКОРИСТАНИХ ДЖЕРЕЛ}

1. Державна служба статистики України [Електронний ресурс]. - Режим доступу: http://www.ukrstat.gov.ua/. Дата звернення: 09.12.2017 p.

2. Про Державний бюджет України на 2015 рік: Закон України від 28.12.2014 p. №80-VIII [Електронний pecypc]. - Режим доступу: http://zakon3.rada.gov.ua/laws/show/80-19

3. Про Державний бюджет України на 2016 рік: Закон України від 25.12.2015 р. №928-VIII [Електронний pecypc]. - Режим доступу: http://zakon2.rada.gov.ua/laws/show/928-19

4. Про Державний бюджет України на 2017 рік: Закон України від 21.12.2016 p. №1801-VIII [Електронний pecypc]. - Режим доступу: http://zakon3.rada.gov.ua/laws/show/1801-19

5. Реформування соціальної політики в Україні: проблеми та перспективи: навч.-наук. вид. / авт. кол. : В.А. Скуратівський, В.П. Трощинський, П.К. Ситник та ін.; за заг. ред. В.А. Скуратівського, В.П. Трощинського. - К.; Львів: НАДУ, 2012. - 368 с.

6. Чекан I.А. Соціальна політика Європейського Союзу: перспективи та шляхи запровадження в Україні [Електронний ресурс] / I.А. Чекан. Режим доступу: http://mev.lac.lviv.ua/downloads/vyklad/chekan/5.pdf (Дата звернення: 07.12.2017)

7. A Long Goodbye to Bismarck? The Politics of Welfare Reforms in Continental Europe / Ed. by Bruno Palier. Amsterdam, Amsterdam University Press, 2010. - 456 p.

8. Euro Area Wage Growth, 2009-2017 [Електронний ресурс]. - Режим доступу: https://tradingeconomics.com/euro-area/wage-growth. Дата звернення: 09.12.2017 p.

9. Eurostat: Your key to European statistics [Електронний ресурс]. - Режим доступу: http://ec.europa.eu/eurostat/web/main/home

10. Kremer M. Doing Good or Doing Better. Developing Policies in a Globalizing World / M. Kremer, P. van Lieshout, R. Went. - Amsterdam: Amsterdam University Press, 2009. - 377 p.

\section{REFERENCES}

1. Derzhavna Sluzhba Statystyky Ukrayiny [State Statistical Service of Ukraine] ukrstat.gov.ua. Retrieved from: http://www.ukrstat.gov.ua/ [in Ukrainian].

2. Pro Derzhavnyy budzhet Ukrayiny na 2015 rik: Zakon Ukrayiny vid 28.12.2014 №80-VIII [On State budget of Ukraine on 2015 year: Law of Ukraine from 28.12.2014 №80-VIII] (n.d.) zakon.rada.gov.ua. Retrieved from: http://zakon3.rada.gov.ua/laws/show/80-19 [in Ukrainian].

3. Pro Derzhavnyy budzhet Ukrayiny na 2016 rik: Zakon Ukrayiny vid 25.12.2015 №928-VIII [On State budget of Ukraine on 2016 year: Law of Ukraine from 25.12.2015 №928-VIII] (n.d.) zakon.rada.gov.ua. Retrieved from: http://zakon2.rada.gov.ua/laws/show/928-19 [in Ukrainian].

4. Pro Derzhavnyy budzhet Ukrayiny na 2016 rik: Zakon Ukrayiny vid 25.12.2015 №928-VIII [On State budget of Ukraine on 2016 year: Law of Ukraine from 25.12.2015 №928-VIII] (n.d.) zakon.rada.gov.ua. Retrieved from:: http://zakon2.rada.gov.ua/laws/show/928-19 [in Ukrainian].

5. Skurativskyy V.A., Troschynskyy V.P. et al. (2012). Reformuvannia sotsialnoyi polityky v Ukrayini: problemy ta perspektyvy [Reforming of social policy of Ukraine: problems and perspectives]. - Kyiv, Lviv : NADU [in Ukrainian].

6. Chekan I.A. (2017). Sotsialna polityka Evropeyskogo Soyuzu: perspektyvy ta shliahy zaprovadzhennia v Ukrayini [Social policy of the European Union: perspectives and ways of implementation in Ukraine]. Retrieved from: http://mev.lac.lviv.ua/downloads/vyklad/chekan/5.pdf [in Ukrainian].

7. Palier Bruno (Ed.). (2010). A Long Goodbye to Bismarck? The Politics of Welfare Reforms in Continental Europe. - Amsterdam, Amsterdam University Press.

8. Euro Area Wage Growth, 2009-2017 (n.d.). Retrieved from: https://tradingeconomics.com/euro-area/wagegrowth

9. Eurostat: Your key to European statistics. Retrieved from: http://ec.europa.eu/eurostat/web/main/home

10. Kremer M., P. van Lieshout, and Went R. (2009). Doing Good or Doing Better. Developing Policies in a Globalizing World. - Amsterdam: Amsterdam University Press.

Одержано 13.03.2018 p. 